\title{
Reduction of Ionosphere Error in GPS for Location Identity
}

\author{
Mohini Ghotekar, Utkarsha Phacharney
}

\begin{abstract}
The Global Positioning System (GPS) has moved toward becoming an amazing tool for ionospheric contemplates. The accuracy of coordination data for the Global Positioning System (GPS) receiver by the GPS monitoring station ought to be expanded. The accuracy can be expanded by deciding the sources of the disturbances that have been delivered by all of ionospheric impacts. The ionospheric delay within the propagation of GPS signal is one among the primary sources of error in GPS precise positioning. The objective of this survey paper is to identify the common factors that affect the accuracy of GPS and identify an effective method which could mitigate or overcome most of those factors. The main objective is the improvement of the measurement accuracy by this correction of ionosphere delay.
\end{abstract}

Keywords: GPS, Klobuchar model, Ne-Quick, Ray Tracing, TEC, GNSS

\section{INTRODUCTION}

Ionosphere is a piece of higher atmosphere with height from $60 \mathrm{~km}$ to more than $1000 \mathrm{~km}$ over the Earth's surface. This layer is portrayed by the free, contrarily charged electrons and positive ions. In spite of the fact that the ionosphere is less than $0.1 \%$ of all out mass of atmosphere, it impacts the worldwide electric circuit, Earth's attractive field and spread of the electromagnetic waves, which experience the ionosphere [1]. There are various Ionospheric delay such as point positioning, short baseline and long Baseline are occur in GPS. The ionospheric delay is a standout amongst the hugest error in GNSS (Global Navigation Satellite System) estimations. The propagation delay in the ionosphere relies upon Total Electron Content (TEC) along the range way between the GNSS satellite and the measurements. The ionospheric refraction additionally changes with range recurrence, geographic area and time [1]. So as to figure and take out the ionospheric delay, GPS (Global Positioning System) framework utilizes an observational model whose parameter esteems are communicate by the satellites.

The range mistake coming about because of the ionospheric delay can be up to $100 \mathrm{~m}$ in magnitude and can

Fundamentally influence the accuracy of the timing, velocity, positioning and navigation. The ionospheric delay

Revised Manuscript Received on November 11, 2019.

* Correspondence Author

Mohini Ghotekar ${ }^{1}$ R.Tiwari College of engineering, Mumbai, Maharashtra, India mohinighotekar21@gmail.com,

Utkarsha Phacharney, 2Datta Meghe College of Engineering, Mumbai, Maharashtra, Indiautk21pac76@gmail.com of dual-frequency Global Navigation Satellite System (GNSS) clients can be exactly amended by estimations from double frequency signals [10]

At first approximation, the ionospheric range error will be calculable as $d=40.3 \frac{\mathrm{TEC}}{\mathrm{f} \times 2}$, where $\mathrm{f}$ indicates the signal frequency and total electron contents represented by TEC. TEC is the integral of the electron density by the side of a ray path as of GNSS receiver to satellite. There are still frequent single-frequency GNSS users who need remedy data to alleviate ionospheric range errors [10].

In next section we will study various methods which are used previously.

\section{REVIEW CRITERIA}

Katarzyna Stepniak et al. in [1], author stated that errors of the Klobuchar model vary from latitude, time and geomagnetic activity. Paper states that Klobuchar model may cause greater errors on the resulting position than neglecting the ionospheric delay. This was the case during the quiet day at mid and high latitudes.

Mardina Abdullah et al. in [2], author describes a new technique for determination of inospheric error to sub-centimetre accuracy. A new approach in the determination of the differential ionospheric error to sub-centimeter accuracy is described in the paper utilizing a developed model. For the standard differential GPS strategy, GPS estimations at two spaced receiving stations; one of which is at a studied area, where the impact of the ionosphere can be resolved and used to address the range estimation at the second station. An ionospheric correction model has been developed to accurately determine the difference in ionospheric delay expected over a short baseline so that a more accurate differential GPS correction can be made. The developed model is a function of elevation angle and TEC.

suzilaYa'acob et al. in [3], author examines Ionospheric Total Electron. The GPS system is used to extract these ionospheric parameters. They had used data for this research from JUPEM. This exploration evaluating the blunders interpreted from the code-deferral to the bearer stage ionospheric discernible by the supposed "Leveling Process", connected to diminish carrier stage ambiguities from the information.

Shiladitya Sen et al. in [4], author had used nonlinear method to smoothing GPS code measurement for this they develops single frequency filter. This technique sums up the Hatch Filter by including a remedy term which is 


\section{Reduction of Ionosphere Error in GPS for Location Identity}

computed through a nonlinear procedure. This method detects gauges the proper amendment term for the Hatch Filter.

Rui Zhang et al. in [5], author explained that, ionosphere modeling accuracy using the single-mode BeiDou system was high in the low- and middle-latitude regions, because the BeiDou satellites had not yet been fully fixed; there are large edge properties at high latitudes. Under the current conditions of few tracking stations and uneven observations distribution, the modeling accuracy of dual-mode satellite system is significantly higher, and the DCB accuracy can also be improved.

Loredana Perrone et al. in [6], author stated that, the ionospheric anomalies that occur during a period of increased auroral activity should not be considered in the analysis this reduces the possibility of polluting the results with external sources. However, author has also showed that some of them could be potential EQ precursors, but before encompassing the analysis to increased auroral activity periods, more investigation is needed.

Ashish Kumar Shukla et al. in [7], author described generation of Klobuchar-like coefficient, especially for EIA region, is demonstrated. These coefficients are optimized over the Indian region using regional TEC data from existing network in India. Further, to accommodate the short-term temporal variability of the ionosphere, a novel prediction methodology was developed. The methodology proposes to broadcast set of new coefficients every $5 \mathrm{~min}$. generated by sing the TEC data of previous $24 \mathrm{~h}$.

Zhen Liu et al. in [8], author explained Algorithm for estimation of ionospheric coefficients using least square method. The algorithm has been tested with measurement driven model data and GAGAN INRES data. Result of paper state that, estimated coefficients provided better ionospheric error correction when compared with ionospheric error correction provided by global (Klobuchar) ionospheric coefficients of GPS. This estimation algorithm will be operationalized at INC Bangalore for providing ionospheric error correction to single frequency user of IRNSS.

Fang Zhou Xue-zhi Yang et al. in [9], author described correction method of ionospheric effects for the space borne SAR imaging. The proposed ionosphere correction algorithm makes use of frequency-dependent phase advance. After removing ionosphere contamination efficiently, a well-focused SAR image can be obtained. The ionosphere correction algorithm does not require strong contrast within the scene, which will conduce to applicability in imaging some areas such as forest field.

Weihua Luoet al. in [10], explained that all ionospheric models generally can reproduce the trend of diurnal ionosphere variations and all the models show better performances in mid-latitude. The NeQuick model has the least accuracy among all the models in regions of China and the PIM model has the best overall performance. The performance of the Klobuchar model is comparable to the PIM model at low-latitude region in China. At some stations, the Klobuchar model is even slightly better than the PIM model.

Renato Filjar et al. in [11], author stated that Ionosphere is the most important source of satellite navigation errors. Successful attempting of the GPS ionospheric delay not only develops the positioning performance of satellite navigation systems, but also enhances the quality of different technical systems based on satellite navigation. Dynamical models appear the most appropriate for direct implementation in user equipment, while physical and empirical models suits well the large systems with high requirements for positioning accuracy.

Zhen Liu et al. in [12], the author explained approach of joint correction of ionospheric phase artifacts and orbital ramp errors in Synthetic Aperture Radar (SAR) imagery using Multiple-Aperture Interferometry (MAI) interferogram and in situ GPS measurements. Paper also shows that systematic treatment of major noise sources in L-band InSAR measurements are critical for accurate measurement of interseismic deformation and need to be combined for continental scale deformation mapping for existing and future L-band SAR missions.

Alessandro Settimi et al. in [13], author represented first simplified step in order to define correction procedure for obtaining a reliable group delay time of ionospheric ray path. In many cases of practical interest, the group delay time depends on geometric length and electron content of ray path. Paper also explained how an oblique radio link can be improved by varying the electron density grid.

Mardina Abdullah et al. in [14], author present modeling estimations to determine distinction in ionosphere-induced deferral between close-by reference stations to exactitude of a metric linear unit. This is with the goal that actual formulae will be patterned to exactly decide the distinction in ionospheric delay expected over a brief baseline thus an more and more precise differential GPS correction are often created.

Jinghua LI et al. in [15], had used data from year 2003 to 2012 from the GPS receiver located at the various locations like Taiwan and Taoyuan. This data is used to examine the long term changes of positioning precision of the singlefrequency GPS receiver. They have used Klobuchar model for Ionospheric delay estimation and correction.

In Guo Ying et al. in [16], author figure outs the position of geomagnetic north-pole in geographic coordinates by using GPS. They had used the transformation model between geomagnetic coordinate system and Klobuchar model and geographic coordinate system for establishment of the algorithm of inverse geomagnetic north-pole based on GPS signals

D. Venkata Ratnam et al. in [17], author tells that they had used Klobuchar ionospheric mode for correction of positioning and ranging errors by the ionosphere. They have told that in low-latitude regions correction of the ionospheric delay based on these coefficients is not accurate because of the large gradients and complex dynamic ionospheric behavior. For this

purpose they have used multishell-spherical harmonics function (MS-SHF) analysis.

Ashraf Farah in [18], author told that NeQuick model gives better result as compare to Klobuchar model for different geographic region in active state of the ionosphere where the ionosphere's variability is high and the TEC values at maximum. This model can 
demonstrate everyday variations in the range delay corrections because of its reliance on every day estimations of normal sun spot number.

Liu Lilong et al. in [19], a new method based on wavelet analysis was developed to tackle the problems like multipath and residual atmospheric errors. Wavelet transform is utilized as an apparatus to isolate methodical errors from the range. They had told that wavelet analysis is good in systematic errors mitigation and its identity extraction. By using wavelet analysis the observation equality improved.

Jin Kyu Choi et al. in [20], author proposed correction error generation algorithm. This algorithm is used for differential positioning performance analysis of navigation equipment. Actualize PC-based verification platform comprised of DGPS reference receiver and GPS simulator to check their proposed remedy blunder age calculation, and think about redress by the proposed correction error generation algorithm with correction determined in correction accessible off-the-shelf beneficiary for DGPS reference station.

Nao Akiyama et al. in [21], affirmed an electric wave from a GPS satellite pass the ionosphere till it touches base to a beneficiary, and it causes the ionosphere delay. Furthermore, ionosphere delay became huge in the daytime when the sun can be seen, and in satellite of low rise edge. In recreation, improvement of situating precision of level bearing and stature course was seen by rectifying the ionosphere delay by Klobuchar Model, IONEX, and double-frequency. Every revision value has trademark and change of correction value different.

H. Munekane et al. in [22], author built up a semi-analytical technique to assess the impact of the second-order ionospheric revision on GPS situating. This technique depends on the semi-analytical positioning error simulation technique created by Geiger and Santerre in which, expecting the ceaseless dispersion of the satellites, a typical condition is framed to assess the situating error taking every one of the commitments of the extending error by the visible satellites into record. About the ionospheric error on transionospheric flag proliferation from satellite to ground ways utilizing promptly accessible GPS satellites using Jones 3-D beam following. The ionospheric deferral or advance is Sergey V. Fridman et al. in [36], had explained the advancement of new HF information absorption capacities for our ionospheric reversal calculation called GPSII. Focused on creating osmosis devices for information identified with HF proliferation channels. Estimations of engendering delay, point of entry, and the ionosphere-prompted Doppler from any number of realized proliferation connections would now be able to be used by GPSII.

A. Kashchey v. et al. in [37], author proposed an estimated system of higher order inosperic error. They had introduced the precise estimation of the higher-request ionospheric blunders dependent on a sensible 3-D electron thickness show. A numerical homing-in beam following calculation is executed to thoroughly figure satellite to collector beam directions. The numerical reproductions performed appeared that higher-request ionospheric remaining extent mistakes may achieve a few centimeters at low and center scopes; be that as it may, at high scopes they scarcely surpass a few millimeters.

Siti Sarah NikZulkifli et al. in [38], author discussed about separation of the beam way to the beneficiary from the satellite decided from the beam following what's more, the separation for proliferation over the observable pathway (LOS) at the speed of light in vacuum. The lingering range mistake (RRE), that is the distinction between the standard double recurrence models adjusted range and LOS, is determined

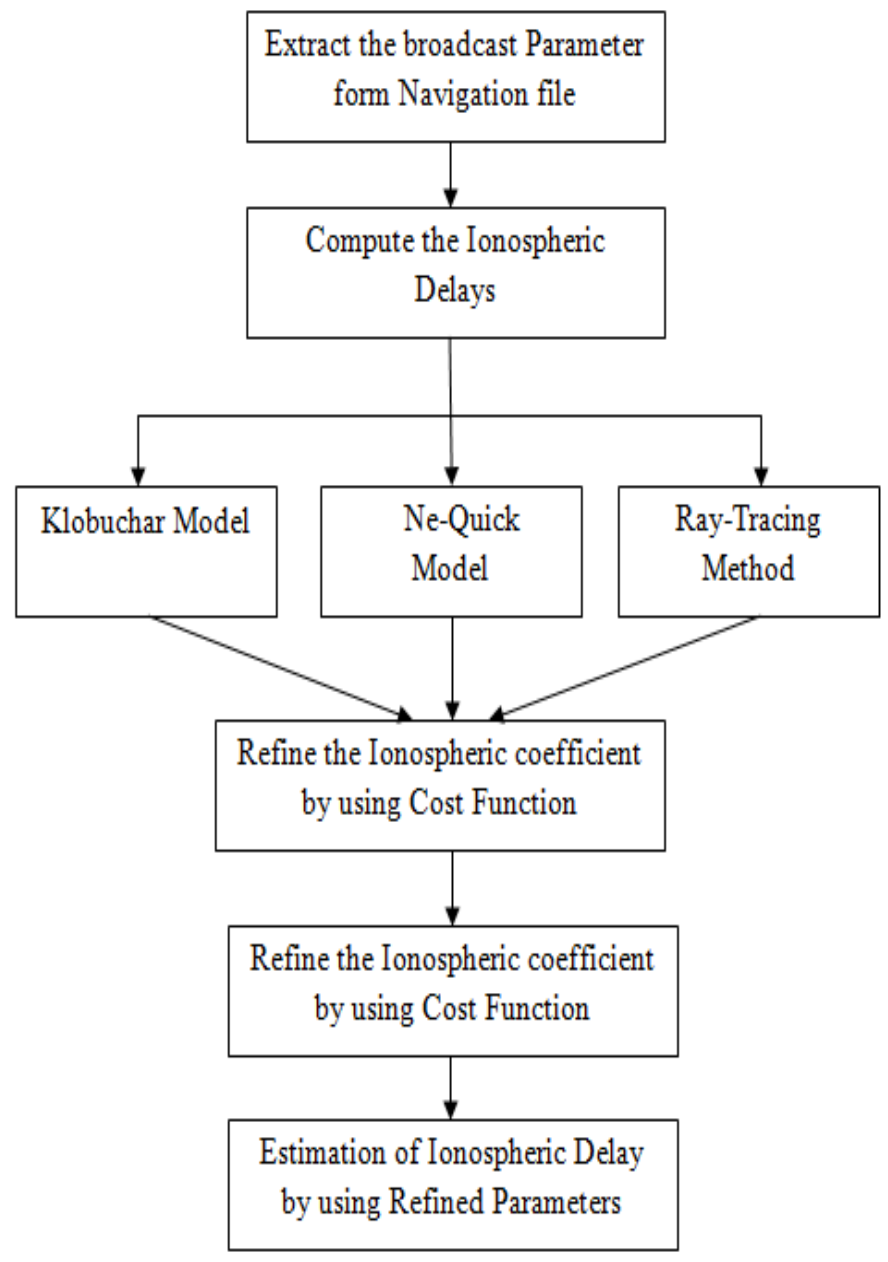

Fig: 1. Implementation of refined Klobuchar, Ne-Quick Models and Ray-Tracing Method

Following table explains the different methods and their result which are used previously. 


\section{Reduction of Ionosphere Error in GPS for Location Identity}

Table I. NeQuick and Klobuchar Performances

\begin{tabular}{|c|c|c|c|}
\hline $\begin{array}{c}\text { Title } \\
\end{array}$ & Author & Method & Result \\
\hline $\begin{array}{l}\text { Nequick Galileo Version Model: } \\
\text { Assessment of a Proposed Version in } \\
\text { Operational Scenario [24] }\end{array}$ & $\begin{array}{l}\text { Salvatore Gaglione, } \\
\text { Antonio Angrisano, } \\
\text { CiroGioia, Anna Innac } \\
\text { and Salvatore Troisi }\end{array}$ & $\begin{array}{l}\text { NeQuick and } \\
\text { Klobuchar }\end{array}$ & Klobuchar one provides higher error. \\
\hline $\begin{array}{l}\text { Ionospheric Range Error Correction } \\
\text { Models [25] }\end{array}$ & $\begin{array}{l}\text { N. Jakowski and M.M. } \\
\text { Hoque }\end{array}$ & $\begin{array}{l}\text { NeQuick and } \\
\text { Klobuchar }\end{array}$ & $\begin{array}{l}\text { They achieve better ionospheric } \\
\text { correction results in transionospheric } \\
\text { ranging when applying the external } \\
\text { models NeQuick or NTCM-GL. }\end{array}$ \\
\hline $\begin{array}{l}\text { Effect of ionosphere refraction on } \\
\text { satellite navigation precision [26] }\end{array}$ & $\begin{array}{l}\text { HAO Jianjun Chip } \\
\text { CHENGF LI Hu HE } \\
\text { Qiushengl }\end{array}$ & $\begin{array}{l}\text { Optic } \\
\text { ray-traced }\end{array}$ & $\begin{array}{l}\text { Optic ray-traced provides more accurate } \\
\text { positioning than Klobuchar model does } \\
\text { for single-frequency receiver, with } \\
\text { slight more computation increased. }\end{array}$ \\
\hline $\begin{array}{l}\text { Variation of single-frequency GPS } \\
\text { Positioning Errors at Taiwan based } \\
\text { on Klobuchar ionosphere model [27] }\end{array}$ & $\begin{array}{l}\text { Jinghua LI and Guanyi } \\
\text { MA }\end{array}$ & $\begin{array}{l}\text { Klobuchar } \\
\text { model }\end{array}$ & $\begin{array}{l}\text { The results showed that during the high } \\
\text { solar activity years the positioning error } \\
\text { is larger. }\end{array}$ \\
\hline $\begin{array}{l}\text { Modelling of ionospheric time delay } \\
\text { of Global Positioning System (GPS) } \\
\text { signals using Taylor series } \\
\text { expansion for GPS Aided Geo } \\
\text { Augmented Navigation applications } \\
\text { [28] }\end{array}$ & $\begin{array}{l}\text { Perumalla Naveen } \\
\text { Kumar, Achanta D. } \\
\text { Sarma, AmmanaSupraja } \\
\text { Reddy }\end{array}$ & $\begin{array}{l}\text { Klobuchar } \\
\text { model }\end{array}$ & $\begin{array}{l}\text { TSE model is estimating delay more } \\
\text { closely with respect to GAGAN data } \\
\text { than that of the Klobuchar and IRI- } 2007 \\
\text { models. }\end{array}$ \\
\hline $\begin{array}{l}\text { Improvement of Indian-Regional } \\
\text { KlobucharIonospheric Model } \\
\text { Parameters for Single-Frequency } \\
\text { GNSS Users [29] }\end{array}$ & $\begin{array}{l}\text { D. VenkataRatnam, J. R. } \\
\text { K. Kumar Dabbakuti, and } \\
\text { N. V. V. N. J. Sri Lakshmi }\end{array}$ & $\begin{array}{l}\text { Klobuchar, } \\
\text { low-latitude, } \\
\text { multishell-sph } \\
\text { erical } \\
\text { harmonics } \\
\text { function } \\
\text { (MS-SHF) }\end{array}$ & $\begin{array}{l}\text { Klobuchar model parameters impart } \\
\text { enhanced ionospheric delay corrections } \\
\text { to regional navigation satellite systems. }\end{array}$ \\
\hline $\begin{array}{l}\text { Accuracy Evaluation of Estimated } \\
\text { Ionospheric Delay of GPS Signals } \\
\text { Based on Klobuchar and IRI-2007 } \\
\text { Models in Low Latitude Region [30] }\end{array}$ & $\begin{array}{l}\text { K. C. T. Swamy, A. D. } \\
\text { Sarma, V. SatyaSrinivas, } \\
\text { P. Naveen Kumar, and P. } \\
\text { V. D. Somasekhar Rao }\end{array}$ & $\begin{array}{l}\text { IRI-2007 and } \\
\text { Klobuchar }\end{array}$ & $\begin{array}{l}\text { Klobuchar model the error in } \\
\text { ionospheric time delay estimation is } \\
\text { reduced from } 26.13 \% \text { to } 6.4 \% \text { by using } \\
\text { the IRI- } 2007 \text { model. }\end{array}$ \\
\hline $\begin{array}{l}\text { Ionospheric Range Error Correction } \\
\text { Models [32] }\end{array}$ & $\begin{array}{l}\text { N. Jakowski and M.M. } \\
\text { Hoque }\end{array}$ & $\begin{array}{l}\text { Klobuchar } \\
\text { model, e } \\
\text { NeQuick } \\
\text { model, and } \\
\text { NTCM-GL } \\
\text { model }\end{array}$ & $\begin{array}{l}\text { NeQuick and NTCM-GL models show a } \\
\text { similar performance which is by a factor } \\
\text { of about } 2 \text { better than the performance } \\
\text { of the Klobuchar model }\end{array}$ \\
\hline $\begin{array}{l}\text { Evaluation of the Impact of } \\
\text { Ionospheric Asymmetry on GNSS } \\
\text { Radio Occultation Inversion } \\
\text { Products using NeQuick and IRI [33] }\end{array}$ & $\begin{array}{l}\text { Shaikh M.M. and } \\
\text { Notarpietro R. }\end{array}$ & $\begin{array}{l}\text { NeQuick2 and } \\
\text { IRI2012 }\end{array}$ & $\begin{array}{l}\text { good correlation between asymmetry } \\
\text { index and Onion-peeling retrieval } \\
\text { errors. }\end{array}$ \\
\hline $\begin{array}{l}\text { Ionospheric correction based on } \\
\text { NeQuick } 2 \text { model adaptation to } \\
\text { Global Ionospheric Maps [34] }\end{array}$ & $\begin{array}{l}\text { Xiao Yu, Weimin Zhen, } \\
\text { Ming Ou and Dun Liu }\end{array}$ & $\begin{array}{l}\text { GIMs-driven- } \\
\text { NeQuick }\end{array}$ & $\begin{array}{l}\text { Performance is better during low solar } \\
\text { activity. }\end{array}$ \\
\hline $\begin{array}{l}\text { Characterization of Multipath } \\
\text { Clusters with Ray-tracing in Urban } \\
\text { MIMO Propagation Environments at } \\
2 \mathrm{GHz} \text { [35] }\end{array}$ & $\begin{array}{l}\text { Thomas Fiigen, Jurgen } \\
\text { Maurer, Werner Sorgel, } \\
\text { and Werner Wiesbeck }\end{array}$ & Ray Tracing & $\begin{array}{l}\text { ray-tracing offers the possibility of } \\
\text { detailed characterization of all } \\
\text { multipath and investigation on } \\
\text { propagation effects }\end{array}$ \\
\hline $\begin{array}{l}\text { Assimilative model for ionospheric } \\
\text { dynamics employing delay, Doppler, } \\
\text { and direction of arrival } \\
\text { measurements from multiple HF } \\
\text { channels [36] }\end{array}$ & $\begin{array}{l}\text { Sergey V. Fridman, L. J. } \\
\text { Nickisch, Mark Hausman, } \\
\text { and George Zunich }\end{array}$ & Ray Tracing & $\begin{array}{l}\text { They had observed that simulated data } \\
\text { are indeed in agreement with } \\
\text { assimilated measurements. }\end{array}$ \\
\hline
\end{tabular}




\begin{tabular}{|l|l|l|l|}
\hline $\begin{array}{l}\text { Estimation of higher-order } \\
\text { ionospheric errors in GNSS } \\
\text { positioning using a realistic 3-D } \\
\text { electron density model [37] }\end{array}$ & $\begin{array}{l}\text { A. Kashcheyev, B. Nava, } \\
\text { and S. M. Radicella }\end{array}$ & Ray Tracing & $\begin{array}{l}\text { Got accurate estimation of the } \\
\text { higher-order ionospheric errors based } \\
\text { on a realistic 3-D electron density model }\end{array}$ \\
\hline $\begin{array}{l}\text { Application of 3-D Ray-Tracing for } \\
\text { Accurate GPS Range Finding [38] }\end{array}$ & $\begin{array}{l}\text { Siti Sarah NikZulkifli, } \\
\text { Mardina Abdullah, and } \\
\text { Mahamod Ismail }\end{array}$ & Ray Tracing & accurate GPS range finding \\
\hline
\end{tabular}

Table II. Comparison of Ionospheric Delay Correction

\begin{tabular}{|l|l|l|l|l|l|l|}
\hline Method & $\begin{array}{l}\text { Complexit } \\
\mathbf{y}\end{array}$ & $\begin{array}{l}\text { Pred } \\
\text { icta } \\
\text { bilit } \\
\mathbf{y}\end{array}$ & $\begin{array}{l}\text { Error } \\
\text { correction } \\
\text { ratio }\end{array}$ & Limitations & $\begin{array}{l}\text { Expansibil } \\
\text { ity }\end{array}$ & Scope \\
\hline IRI & $\begin{array}{l}\text { Relatively } \\
\text { simple }\end{array}$ & Yes & About $60 \%$ & $\begin{array}{l}\text { In China the results have } \\
\text { different degrees of deviation }\end{array}$ & Worse & $\begin{array}{l}\text { For rapid global } \\
\text { localization }\end{array}$ \\
\hline Klobuchar & Simple & Yes & $50 \sim 60 \%$ & $\begin{array}{l}\text { Limited to the mid-latitude } \\
\text { areas, but cannot effectively } \\
\text { reflect the real situation of the } \\
\text { ionosphere }\end{array}$ & Worse & $\begin{array}{l}\text { WAAS and broadcast } \\
\text { ephemeris }\end{array}$ \\
\hline $\begin{array}{l}\text { Georgiadou } \\
\text { Simple }\end{array}$ & No & $\begin{array}{l}\text { Better than } \\
\text { Klobuchar }\end{array}$ & $\begin{array}{l}\text { Limited to the mid-latitude } \\
\text { areas }\end{array}$ & areas Better & WAAS \\
\hline $\begin{array}{l}\text { Bual-frequ } \\
\text { ency } \\
\text { correction }\end{array}$ & Simple & No & About $90 \%$ & $\begin{array}{l}\text { Not suitable for single } \\
\text { frequency users }\end{array}$ & Better & Broadcast ephemeris \\
\hline $\begin{array}{l}\text { Differential } \\
\text { correction } \\
\text { method }\end{array}$ & Simple & No & $\begin{array}{l}\text { Better, Limited } \\
\text { accuracy of the } \\
\text { base station }\end{array}$ & $\begin{array}{l}\text { Not suitable for long baseline } \\
\text { Users }\end{array}$ & General & $\begin{array}{l}\text { Short baseline relative } \\
\text { localization or differential } \\
\text { correction localization near } \\
\text { the base station }\end{array}$ \\
\hline
\end{tabular}

message and the likely geographical area for single -

A comparative study of Klobuchar, Ne-Quick models and other models and their implementations to calculate the ionosphere delay. The models calculate the delay but due to perturbed situations in ionosphere layer the estimations are not that precise, like for low and mid-latitudes the Klobuchar model usually underestimates ionospheric delay, while for the high latitudes the ionosphere delay is overestimated. An algorithm named as Ray tracing algorithm will be used which provides the group delay measurement on the basis of variations of electron density in ionosphere layer. A method is Proposed which includes, the ray tracing algorithm integrated with Klobuchar rmodel is expected to compute the precise ionosphere delay and reduce to some extent. Following figure shows the implantation of Klobuchar, Ne-Quick models and racing method.

\section{A. Klobuchar Ionosphere Model}

The Klobuchar model was the first ionospheric satellite positioning correction method developed. Since the 1980s, it has been used in GPS satellites [28]. The Klobuchar model was designed to remove about $50 \%$ of the ionospheric pseudo-range error while requiring a small number of coefficients and a low computational time for the user. Its design was a compromise between the user's computational complexity, the knowledge of TEC variations, the number of coefficients available in the ionosphere correction satellite frequency users at the time [29]

\section{B. NeQuick G Ionosphere model}

The model NeQuick $G$ is controlled by three coefficients transmitted with the message of Galileo satellite navigation. The NeQuick G model is designed to remove at least $70 \%$ of the ionospheric error under any conditions, with the exception of periods when the ionosphere is greatly disturbed. This can happen during geomagnetic storms, for example. Compared to the Klobuchar model, for example, the NeQuick G model is computationally demanding but it is also more accurate [34].

\section{Ray Tracing Algorithm}

The ray tracing algorithms calculate the coordinates of the wave vector and its three components according to the ray theory. The calculated group time delay tcalc of the wave along the path is another important quantity. The group time delay is a useful quantity that allows checking a ray tracing algorithm performance when an ionospheric model is assumed to be correct. We plan to implement a ray tracing algorithm in order to obtain a quantity to replace measured group time delay treal value from an actual measurement. $[37,38]$. By using above three techniques we can calculate the group delay in GPS system.

Table II depicts the performance evaluation of all the three ionospheric models. 


\section{Reduction of Ionosphere Error in GPS for Location Identity}

These results clearly show that the rms errors (RMSEs) and AEs were larger, in the descending order of Klobuchar model, ion correction model, and the refined Klobuchar model. As per RMSE results in Table II, the refined Klobuchar model was found to be better than the original Klobuchar model and ion correction model $(21.53 \% / 50.88 \%)$ and $(62.69 \% / 77.08 \%)$. The generated model coefficients are expected to predict the actual variation in TEC [39].

Table III Original and Refined Klobuchar Parameters on July 22 and 25,2004

\begin{tabular}{ccccccc}
\hline \hline Parameters & $\begin{array}{c}\text { Refined } \\
\text { Klobuchar } \\
\text { Model }\end{array}$ & $\begin{array}{c}\text { Klobuchar } \\
\text { Model [1] }\end{array}$ & $\begin{array}{c}\text { Ion Correction } \\
\text { Model [11] }\end{array}$ & $\begin{array}{c}\text { Refined } \\
\text { Klobuchar } \\
\text { Model }\end{array}$ & $\begin{array}{c}\text { Klobuchar } \\
\text { Model [1] }\end{array}$ & $\begin{array}{c}\text { Ion Correction } \\
\text { Model [11] }\end{array}$ \\
\hline$\alpha_{0}$ & $5.86 \mathrm{E}-09$ & $1.74 \mathrm{E}-08$ & $1.11 \mathrm{E}-08$ & $3.90 \mathrm{E}-09$ & $1.92 \mathrm{E}-08$ & $1.11 \mathrm{E}-08$ \\
$\alpha_{1}$ & $-4.18 \mathrm{E}-08$ & $2.24 \mathrm{E}-08$ & $2.23 \mathrm{E}-08$ & $-1.00 \mathrm{E}-08$ & $1.42 \mathrm{E}-08$ & $2.23 \mathrm{E}-08$ \\
$\alpha_{2}$ & $-4.12 \mathrm{E}-07$ & $-3.74 \mathrm{E}-07$ & $-5.96 \mathrm{E}-08$ & $7.59 \mathrm{E}-07$ & $-3.83 \mathrm{E}-07$ & $-5.96 \mathrm{E}-08$ \\
$\alpha_{3}$ & $1.718-05$ & $5.71 \mathrm{E}-07$ & $-1.19 \mathrm{E}-07$ & $4.53 \mathrm{E}-06$ & $5.99 \mathrm{E}-07$ & $-1.19 \mathrm{E}-07$ \\
$\beta_{0}$ & $1.06 \mathrm{E}+05$ & $1.29 \mathrm{E}+05$ & $1.064 \mathrm{E}-05$ & $1.05 \mathrm{E}+05$ & $1.34 \mathrm{E}+05$ & $1.06 \mathrm{E}-05$ \\
$\beta_{1}$ & $2.11 \mathrm{E}+05$ & $2.12 \mathrm{E}+05$ & $1.47 \mathrm{E}-05$ & $1.70 \mathrm{E}+05$ & $1.70 \mathrm{E}+05$ & $1.47 \mathrm{E}-05$ \\
$\beta_{2}$ & $-2.29 \mathrm{E}+04$ & $-2.29 \mathrm{E}+04$ & $-6.55 \mathrm{E}-04$ & $-1.09 \mathrm{E}+06$ & $-1.09 \mathrm{E}+06$ & $-6.55 \mathrm{E}-04$ \\
$\beta_{3}$ & $2.73 \mathrm{E}+05$ & $2.74 \mathrm{E}+05$ & $-3.27 \mathrm{E}-05$ & $3.26 \mathrm{E}+06$ & $3.27 \mathrm{E}+06$ & $-3.27 \mathrm{E}-05$ \\
DC & $3.22 \mathrm{E}-9$ & $5.00 \mathrm{E}-09$ & $5.00 \mathrm{E}-09$ & $3.25 \mathrm{E}-09$ & $5.00 \mathrm{E}-09$ & $5.00 \mathrm{E}-09$
\end{tabular}

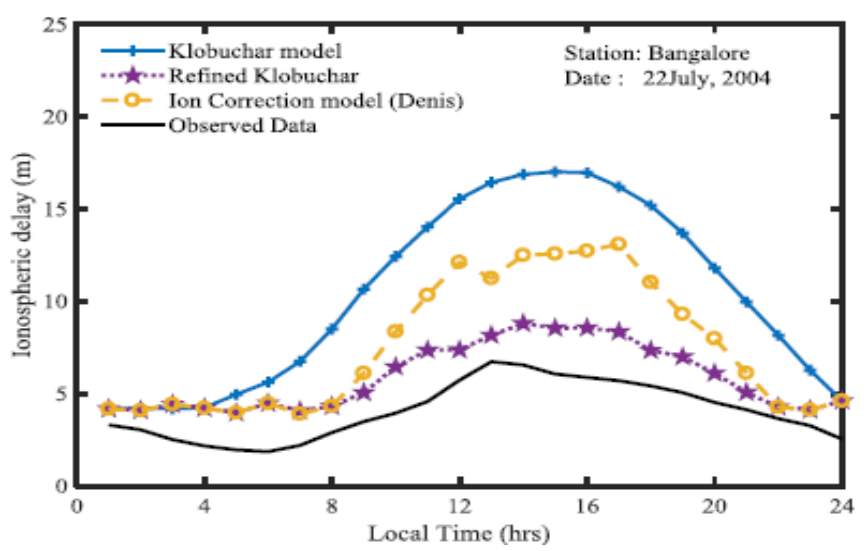

Fig: 3. Estimated Ionospheric Delay at the Bengaluru Station on quiet day July 22, 2004.

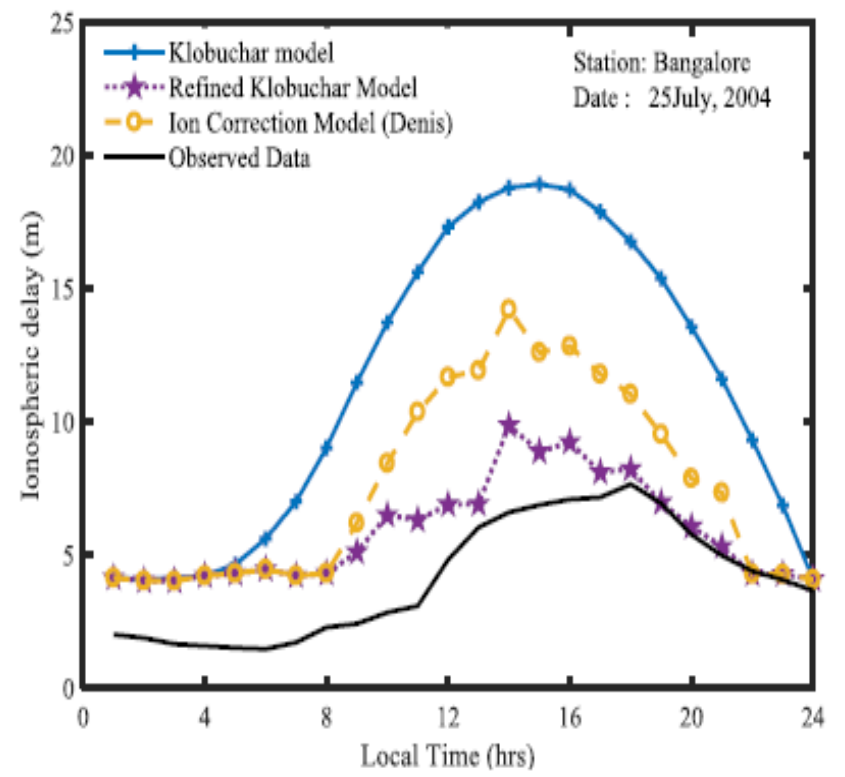

Fig: 4. Estimated Ionospheric Delay at the Bengaluru Station on disturbed day July 25, 2004.

\section{CONCLUSION}

As we seen that the Global Positioning System has moved toward becoming an amazing tool for ionospheric contemplates. The ionospheric delay within the propagation of Global Positioning System (GPS) signal is one among the sources of error in GPS precise positioning. The GPS positioning accuracy is greatly affected by several errors, out of which ionosphere delay has been significant. The main objective is to reduce the errors in GPS positioning for precise accuracy. We have studied various research, they had shown various methods to reduce the errors in GPS positioning. From this study it is clear that Klobuchar model and Ne-Quick model for calculation of ionosphere delay can be implemented to have better result. We had also studied the Ray Tracing method which can be used for calculation of group delay function.

\section{REFERENCES}

1. Katarzyna Stepniak, Pawel Wielgosz and Jacek Paziewski, “Accuracy analysis of the Klobuchar ionosphere model transmitted by the GPS system," 9th Conference Environmental Engineering, 2014

2. Norsuzila Ya'acob, Mardina Abdullah and Mahamod Ismail, "Ionospheric Modelling: Improving the Accuracy of Differential GPS (dGPS) in Equatorial Regions," IEEE, 2007

3. Suzila Ya'acob, Mahamod Ismail and Mardina Abdullah, "Investigation of the GPS Signals Ionospheric Correction: Ionospheric TEC Prediction over Equatorial,” 2007 IEEE International Conference on Telecommunications and Malaysia International Conference on Communications, 14-17 May 2007

4. Shiladitya Sen and Jason Rife, "Reduction of Ionosphere Divergence Error in GPS Code Measurement Smoothing by Use of a Non-Linear Process," pp- 312-320, 2008

5. Rui Zhang, Wei-wei Song, Yi-bin Yao, Chuang Shi, Yi-dong Lou and Wen-ting Yi, "Modeling regional ionospheric delay with ground-based BeiDou and GPS observations in China," Springer, 19 November 2013

6. Loredana Perrone, Angelo De Santis, Cristoforo Abbattista, Lucilla Alfonsi, "Ionospheric anomalies detected by ionosonde and possibly related to crustal earthquakes in Greece," Published by Copernicus Publications on behalf of the European Geosciences Union, 2018.

7. Ashish Kumar Shukla, Saurabh Das, Atul P. Shukla, Vilas S. Palsule, "Approach for near-real-time

8. prediction of ionospheric delay using Klobuchar-like coefficients for Indian region," IET , Vol. 7, Iss. 1, pp. 67-74, 2013

9. Zhen Liu, Hyung-Sup Jung and Zhong Lu, "Single Frequency Ionospheric Error Correction using Coefficient generated from regional Ionosperic Data for IRNSS," Indian Journal of Radio and Space Physics, Vol. 42, pp. 125-130, June 2013

10. Fang Zhou Xue-zhi Yang, Guang-caiSunandMeng-dao Xing, "Ionosphere Correction Algorithm for P-band Spaceborne SAR Imaging," IEEE, pp 717-719, 2015

11. WeihuaL uo, Zhizhao Liu and Min Li, "A preliminary evaluation of the performance of multiple ionospheric models in low- and mid-latitude regions of China in 2010-2011," Springer, 20 June 2013

12. Renato Filjar, Tomislav Kos and Ivan Markezic, "GPS Ionospheric Error Correction Models," 48th International Symposium ELMAR-2006, 07-09 June 2006

13. Zhen Liu, Hyung-Sup Jung and Zhong Lu, "Joint Correction of Ionosphere Noise and Orbital Error in L-Band SAR Interferometry of Interseismic Deformation in Southern California," IEEE Transactions On Geoscience And Remote Sensing, VOL. 52, NO. 6, June 2014

14. Alessandro Settimi, Michael Pezzopane, Marco Pietrella, Carlo Scotto, Silvio Bianchi, James A. Baskaradas, "Correction's method of the electron density model in ionosphere by ray tracing techniques," Advances in Space Research 55, pp.1630-1639, 2015 
15. Mardina Abdullah, Hal J. Strangeway, David M.A. Walsh, "Improved Ionospheric Error Correction for differential GPS," 2003 Asia-Pacific Conference on Applied Electromagnetic, pp. 83-87, 2003

16. Jinghua LI and Guanyi MA, "Variation of single-frequency GPS Positioning Errors at Taiwan based on Klobuchar ionosphere model," IEEE, 2014

17. Guo Ying, and Cheng Pengfei, "Inversion of Geomagnetic North-Pole Using GPS Signal and KlobucharIonospheric Algorithm," IEEE, pp. 1741-1743, 2011

18. D. Venkata Ratnam, J. R. K. Kumar Dabbakuti, and N. V. V. N. J. Sri Lakshmi, "Improvement of Indian-Regional KlobucharIonospheric Model Parameters for Single-Frequency GNSS Users,” IEEE Geoscience and Remote Sensing Letters, IEEE, 2018

19. Ashraf Farah, "NeQuick 2 model for single-frequency ionospheric delay mitigation," Journal of Geomatics, Vol. 10 No. 2 October 2016

20. Liu Lilong, Wen Hongyan and Liu Bin, "Mitigation of Systematic Errors of GPS Positioning Based on Wavelet Denoise," 2010 Second WRI Global Congress on Intelligent Systems, pp. 253-255, 2010

21. Jin Kyu Choi, Sang Hyun Park, Deuk Jae Cho, and Ki YeolSeo, "Correction Error Generation Algorithm for Differential Positioning Performance Analysis of Navigation Equipment," International Conference on Control, Automation and Systems 2008 Oct. 14-17, 2008

22. Nao Akiyama, Toshiyuki Tanaka and Masashi Yonekawa, "Improvement of GPS positioning accuracy by ionosphere delay correction," SICE Annual Conference 2007 Sept. 17-20, 2007

23. H. Munekane, "A semi-analytical estimation of the effect of second-order ionospheric correction on the GPS positioning," Geophys. J. Int. 163, pp. $10-17,2005$

24. Jun Hao and ShuxiaGuo, "The Study of Dual Frequency Ionospheric Error Correction Method and Accuracy Analysis Based on GPS," 14-16 Sept. 2011

25. Salvatore Gaglione, Antonio Angrisano, CiroGioia, Anna Innac and Salvatore Troisi, "Nequick Galileo Version Model: Assessment if a Proposed Version in Operational Scenario," IEEE International Geoscience and Remote Sensing Symposium, pp. 3611 - 3614, 2015 